\title{
REMOVAL OF LEAD (II) FROM SYNTHETIC SOLUTION BY ADSORPTION ONTO COAL MINING WASTE MATERIAL
}

\author{
H. L. Yadav* and A.Jamal \\ Department of Mining Engineering, Indian Institute of Technology, (BHU) Varanasi, India \\ *E-mail: hiralalyd@gmail.com
}

\begin{abstract}
Coal/metals, mining, ore processing, and smelting activities pollute water resources with heavy metals all over the world. In this paper, mine waste materials (sandstone) obtained from mine site was used for the uptake of Lead (Pb) ions from the synthetic solution. Laboratory analysis was conceded to study the effects of adsorption parameter like, $\mathrm{pH}$, temperature, contact time, adsorbents dose, on Lead adsorption; the obtained experimental data showed that adsorption of waste materials had a higher adsorption capacity at shorter contact time at $\mathrm{pH}$ 5.0. The present investigation demonstrates the sandstone as mine waste material can be effectively utilized for the treatment of Lead (II) laden synthetic solutions by adsorption process.
\end{abstract}

Keywords: waste materials, Lead (II) ions, adsorption, synthetic solution, health effects.

(C) RASĀYAN. All rights reserved

\section{INTRODUCTION}

The pollution of the natural environment with many toxic substances has been on the increase in recent years as a result of the rapid growth of different industries worldwide. The heavy metal contamination shows a major menace for all living organisms. ${ }^{1,2}$ Due to its toxicity and nonbiodegradability, these heavy metal ions have a tendency to accumulate in living organisms, which are conceivably leading to numerous of serious harmful disease $^{3-6}$ in the human body and deem as severe toxic for all creature ${ }^{7}$. These metals are mostly $\mathrm{Cd}, \mathrm{Cr}, \mathrm{Cu}$, $\mathrm{Pb}, \mathrm{Hg}, \mathrm{Ni}$, and $\mathrm{Zn}{ }^{7}$

These toxic materials may be derived from many geogenic and anthropogenic sources such as different mining (coal/metal) operations ${ }^{8,9}$, oil refining, ores, sludge disposal, fly ash from thermal power plants and municipal incinerators, handing out of radioactive materials, metal plating, or the manufacture of different electrical and electronics equipment, alloys, batteries, paints, pesticides or preservatives. (WHO). Lead ions is a metal, present in the $4^{\text {th }}$ group of periodic table with atomic number 82 , atomic mass 207.2 , atomic weight 207.19 , density 11.4 $\mathrm{gcm}^{-3}$, specific gravity 11.34 , melting and boiling point respectively $327.5{ }^{\circ} \mathrm{C}$ and $1740^{\circ} \mathrm{C}$, having a broad application in many industries, such as battery and printed wiring board manufacturing. ${ }^{10,11}$ Therefore huge amounts of lead polluted industrial effluents are discharged into the natural water environment without proper treatment, severally influence the surrounding water resources. This water causes severe human health nuisance ${ }^{12-14}$ and causes acute toxic and carcinogenic effect. ${ }^{15,16}$ Lead leaden water also degrades the surrounding quality of the natural environment as well as the severe effect on animal's health ${ }^{17}$ with aquatic flora and fauna. Lead $(\mathrm{Pb})$ also damage the human organs like liver, brain, kidneys, central nervous system, renal damage, cardiovascular, developmental, endocrinological, gastrointestinal, hematopoietic, musculoskeletal disorder, neural, immunological and reproductive systems ${ }^{18}$ birth defects and reproductive system. ${ }^{19,20}$ Lead concentrations in the ranges of 0.01 to $5.0 \mathrm{mg} / \mathrm{L}^{21}$ produce many serious harmful diseases like anaemia, encephalopathy, hepatitis, and nephritic syndrome ${ }^{22}$ in human. To protect human health from poisoning, many Renault regulatory bodies have prescribed the maximum limits of few heavy metals like, $\mathrm{Cd}, \mathrm{Cu}, \mathrm{Cr}, \mathrm{Hg}, \mathrm{Ni}$, $\mathrm{Pb}, \mathrm{Se}$ and $\mathrm{Zn}^{17,23}$ in drinking water. At present, the maximum permissible limit of lead $(\mathrm{Pb})$ ions, $0.015 \mathrm{mg} / \mathrm{L}$, and $0.01 \mathrm{mg} / \mathrm{L}$ respectively prescribe by imperative agencies ${ }^{23}$ in drinking water. To meet this recommends permissible limits of Lead $(\mathrm{Pb})$ concentrations, effective and economical treatment process is required for Lead removal for mining and industrial effluents. A number of treatment methods have been effectively used for the elimination of toxic heavy metals from acid mine drainage. These methods are neutralization ${ }^{24}$, precipitation ${ }^{25-}$ 
${ }^{28}$, electrochemical remediation ${ }^{29}$, oxidation and hydrolysis ${ }^{30}$, ion exchange ${ }^{31}$ titration $^{32}$, bio sorption, ${ }^{33}$ adsorption, ${ }^{1,2,34-47}$ reverse osmosis. ${ }^{48}$

\section{Material and Methods}

\section{EXPERIMENTAL}

The water sample was collected in plastic containers, which was thoroughly washing with the sample water before sampling acid mine drainage from the inactive open-cast coal mines (Gorbi, Singrauli, India). The $\mathrm{pH}$, TDS, temperature, salinity and conductivity were measured in the field using a Hanna multi-parameter (HI 9828).Natural sandstone was collected from the mine site and crushed in a ball mill, and then sieved and particles ranging from 75 to $150 \mu \mathrm{m}$ were used for the study. Characteristic of sandstone through XRF analysis shown in the Table-1, contain a high amount of Silica $\left(\mathrm{SiO}_{2}\right), 67.87 \%$ and Alumina $\left(\mathrm{Al}_{2} \mathrm{O}_{3}\right), 25.43 \%$. It was used as the effective low-cost adsorbent for the Lead uptake from the synthetic solution. The $\mathrm{pH}$ value was measured by using a Multiparameter, $\mathrm{pH}$ meter (Hanna, 9828). The concentrations of Lead in the solution were determined by using a heavy metals analyzer (HM 1000), and similar synthetic water solution is prepared in the laboratory by using AR Grade chemicals for analysis.

\section{Batch Adsorption Experiments}

The batch adsorption process was carried out by mixing 2 to 12 grams of sandstone powder with $200 \mathrm{ml}$ of synthetic solution in $250 \mathrm{ml}$ conical flasks, shaking in a Borg shaker at $190 \mathrm{rpm}$ for a time of 300 minutes. After shaking the adsorbent was separated using a what man filter paper $0.45 \mu \mathrm{m}$ size and filtrate were analyzed for Lead $(\mathrm{Pb})$ concentrations by the heavy metals analyzer (HM1000). The $\mathrm{pH}$, temperature, TDS, salinity and Electrical conductivity were measured by $\mathrm{pH}$ meter Hanna, (HI 9828 series).Study the effect of sandstone for different experimental parameters, i.e., the initial concentration of metal, $\mathrm{pH}$ value, agitation rate, shaking time and adsorbent sizes and dosage.

\section{Effect of sandstone dosage}

\section{RESULTS AND DISCUSSION}

In the adsorption process, adsorbent dosage plays a major role in removal efficiency. Figure 1, shows the experimental results obtained from equilibrium adsorption study for Lead ions removal efficiency vs. Sandstone dose at a constant Lead ion concentration $(0.277 \mathrm{mg} / \mathrm{L})$ with varying dosage of sandstone $(2,4,6,8,10,12 \mathrm{gm})$. The obtained result shows that the removal efficiency of sandstone depends on its dosage, while it metal removal efficiency decreases with decrease the adsorbent dosage. This is due to increasing the number of active sites, which provide more opportunity to metals ion to bind with active sites and attract metal ions onto the adsorbent material. $^{49}$

\section{Effect of Concentration}

The lead removal efficiency of sandstone was studied at different Lead ions concentration range, varying from 0.0010 to $0.277 \mathrm{mg} / \mathrm{L}$, at a constant dose of sandstone, $4 \mathrm{gm}$. Fig.-2. Shows that the uptake efficiency of sandstone also depends on the initial concentration of Lead ions in the synthetic solution. The study results showed a gradual decrease in the Lead removal capacity of sandstone, when the lead concentration increased in the solution. This decrease is due to the fact that at higher concentrations, the accessible sites become rarer on the number of ions present in synthetic solution. At the lower range of Lead concentration, the ratio between a number of available sites and metal ions concentration in the adsorption process is stumpy; so as a result, the adsorbed ions portion becomes sovereign from the primary range of concentration. The lead ions adsorption capacities of sandstone were reduced from $100 \%$ to $70 \%$. So the metal removal efficiency depends on initial metal ions concentration ${ }^{50}$ of the synthetic solution.

\section{Effect of adsorbent size}

To obtain the optimal size of adsorbent, a sample of sandstone was studied by constant dose with a varying Particle size in the range of $75 \mu \mathrm{m}, 106 \mu \mathrm{m}, 125 \mu \mathrm{m}$, and $150 \mu \mathrm{m}$. The tests were investigated using initial Lead concentrations of $0.277 \mathrm{mg} / \mathrm{L}$ at the room temperature. Obtain the results are shown in Fig.-3, represented that the removal percentage increase with decrease the particle size of the adsorbent. This is due to increase the surface area of the adsorbent. 


\section{Effect of pH}

In adsorption process, $\mathrm{pH}$ plays a significant role in removal efficiency. To obtain the optimal $\mathrm{pH}$ of a sample of sandstone was studied with varying range of $\mathrm{pH}$ value 1.5 to 5 . The tests were investigated using initial Lead concentrations of $0.277 \mathrm{mg} / \mathrm{L}$ at the room temperature. Obtain the results are shown in Fig.-4 represented that the removal percentage increase with increasing the $\mathrm{pH}$ of the solution because of the lower $\mathrm{pH}$ range, the concentration of $\mathrm{H}^{+}$is comparatively higher in solution, the rivalry for binding sites on the adsorbent surface with metal ions also increases resulting in a poorer efficiency of metal removal ${ }^{51}$.As solution $\mathrm{pH}$ increases, the negatively charged functional groups on the adsorbent surface, resulting in the enhancement of binding between metal ions and adsorbent. In this experimental study, when the $\mathrm{pH}$ value increased, the removal capacity of adsorbent also increased up to certain stages before it started declining at a slower rate or remains in constant.

\section{Effect of contact time}

In the adsorption studies, contact time is also an important parameter. This generally involves with the adsorbent surface and active sites of saturation. To obtain the optimal time of the adsorbent (sandstone) was studied by using a fixed dose of the adsorbent with a variable time interval. The selected time intervals were varied from $30 \mathrm{~min}$ to $300 \mathrm{~min}$ (i.e., 30, 60, 120, 180,240 and $300 \mathrm{~min}$.). Obtain the results are shown in Fig.-5 represented that the reaction between the metal ions and active site binding, which are comparatively rapid throughout the intake phase of metals exposure. Thus, the active sites are getting engaged by metal ions which resulted in the remaining ions engage each other for free active sites ${ }^{52}$, the removal percentage increase with the increase, the adsorbent time. This is due to the increased surface area of the adsorbent, greater availability of exchange sites and presence of more adsorption sites.

\section{Effects of temperature}

The effects of temperature on Lead removal were investigated at a varying range of temperatures $(25,30$, and $50^{\circ} \mathrm{C}$ ) for five hours. Temperatures were adjusted using a temperature controlled orbital shaker. Fig.-6 represented that the removal percentage increase with increasing the temperature up to a certain limit.

\section{Effect of electrical conductivity}

The electrical conductivity of the treated water sample decreased over time (Fig.-7), by the end of the experimental analysis, the EC had reduced to $741 \mu \mathrm{S} / \mathrm{cm}$. This was almost $65 \%$ of the removal of initial Electrical Conductivity of the raw water sample, indicating the removal of metals from a water sample.

\section{Effect of total dissolved solids (TDS)}

The concentration of total dissolved solids (TDS) in the raw AMD was $1250 \mathrm{mg} / \mathrm{L}$. When the water sample was treated by the sandstone, the TDS in the sample, subsequently decreased (shown in Fig.-8), $370 \mathrm{mg} / \mathrm{L}$.

\section{Effect of Salinity}

Salinity in water found due to an excess concentration of dissolved salts, which affects the water quality. The higher level of salinity in water decreased the concentration of dissolved oxygen. The salinity level in the solution before treatment was 1.12 PSU. After treatment by sandstone, the range of salinity concentration in the sample, subsequently decreased (Fig.-9) from 1.12 PSU to 0.36 PSU.

Table-1: Shows the chemical composition of sandstone

\begin{tabular}{l|l|l}
\hline S.No. & Oxides & \% Content \\
\hline 1 & Silica $\left(\mathrm{SiO}_{2}\right)$ & 67.87 \\
\hline 2 & Alumina $\left(\mathrm{Al}_{2} \mathrm{O}_{3}\right)$ & 25.43 \\
\hline 3 & Ferric oxide $\left(\mathrm{Fe}_{2} \mathrm{O}_{3}\right)$ & 2.27 \\
\hline 4 & Calcium oxide $(\mathrm{CaO})$ & 1.70 \\
\hline 5 & Titanium dioxide $\left(\mathrm{TiO}_{2}\right)$ & 0.086 \\
\hline 6 & Potassium oxide $\left(\mathrm{K}_{2} \mathrm{O}\right)$ & 0.560 \\
\hline 7 & Nickel(II) oxide $(\mathrm{NiO})$ & 0.212 \\
\hline
\end{tabular}


RASĀYAN J. Chem.

Vol. 10 | No. 3 |1062 - 1067 | July - September | 2017

\begin{tabular}{l|l|l}
\hline 8 & Manganese oxide $(\mathrm{MnO})$ & 0.220 \\
\hline 9 & Phosphorus pentaoxide $\left(\mathrm{P}_{2} \mathrm{O}_{5}\right)$ & 0.021 \\
\hline 10 & Chromium(III) oxide $\left(\mathrm{Cr}_{2} \mathrm{O}_{3}\right)$ & 0.628 \\
\hline 11 & Vanadium(V) oxide $\mathrm{V}_{2} \mathrm{O}_{5}$ & 0.0053 \\
\hline
\end{tabular}

- 5 of Leso

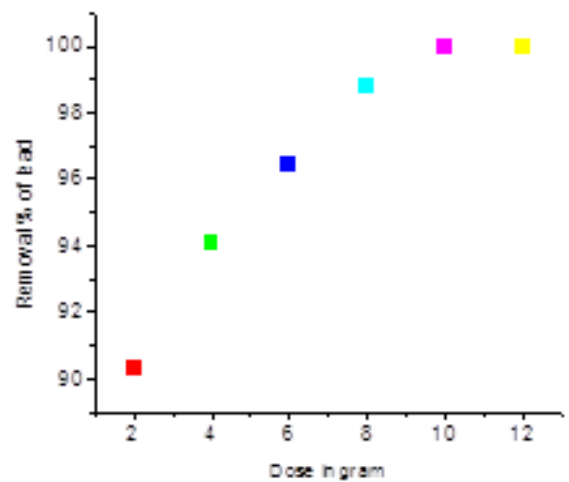

Fig.-1: Effect of dose on the removal of Lead $(\mathrm{Pb})$

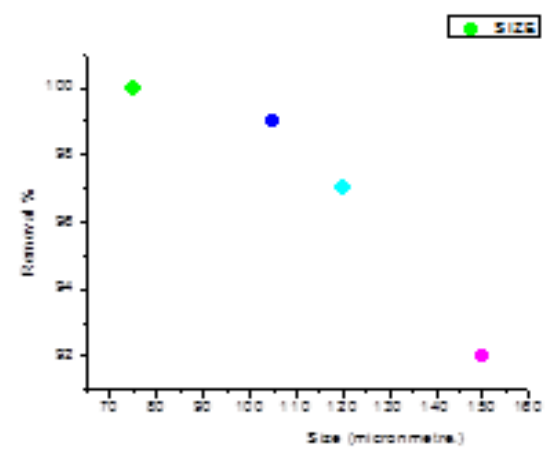

Fig.-3: Effect of size on the removal of Lead $(\mathrm{Pb})$

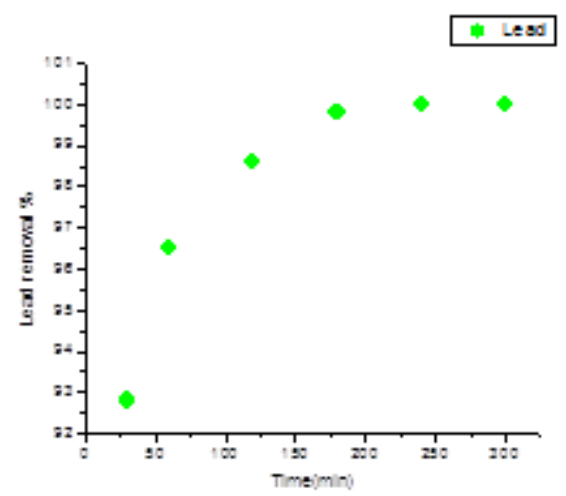

Fig.-5: Effect of time on the removal Lead $(\mathrm{Pb})$

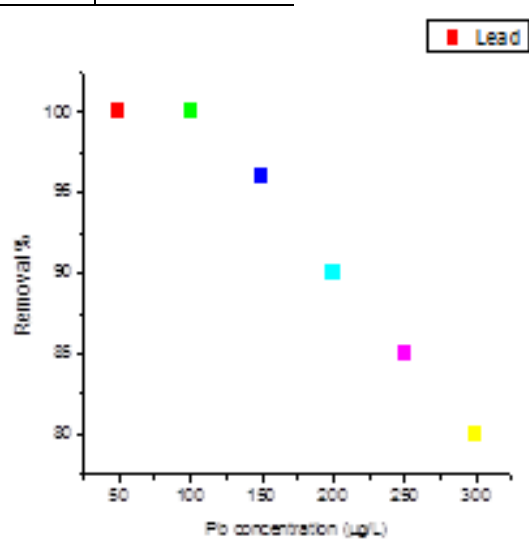

Fig.-2: Effect of concentration on the removal of Lead $(\mathrm{Pb})$

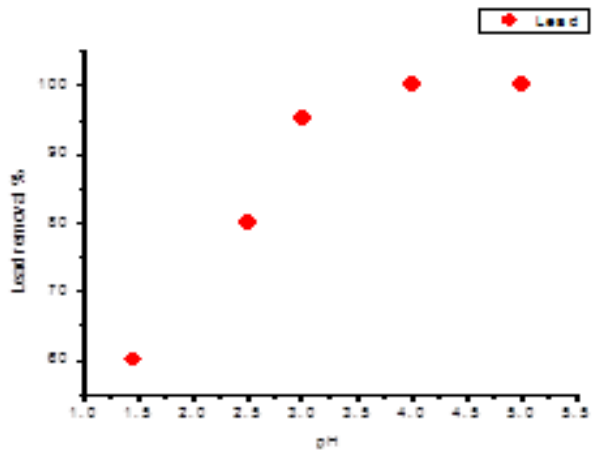

Fig.-4: Effect of $\mathrm{pH}$ on the removal of Lead $(\mathrm{Pb})$

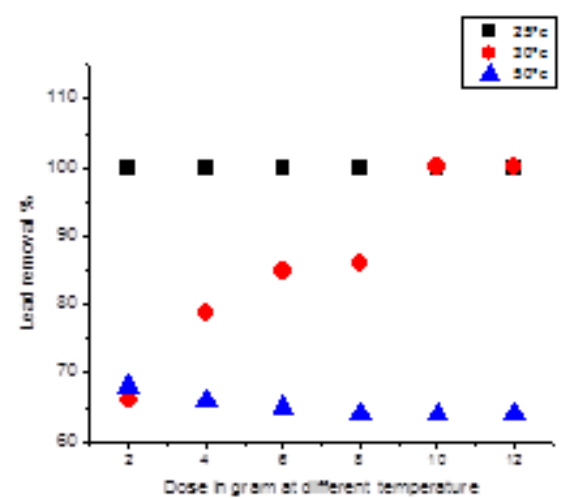

Fig.-6: Effect of temperature on the removal of Lead $(\mathrm{Pb})$ 
RASĀYAN J. Chem.

Vol. 10 | No. 3 |1062 - 1067 | July - September | 2017

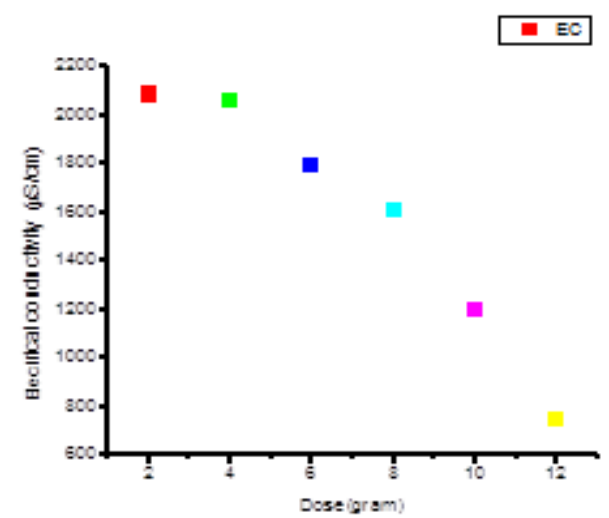

Fig.-7: Effect of EC. on the removal of Lead $(\mathrm{Pb})$

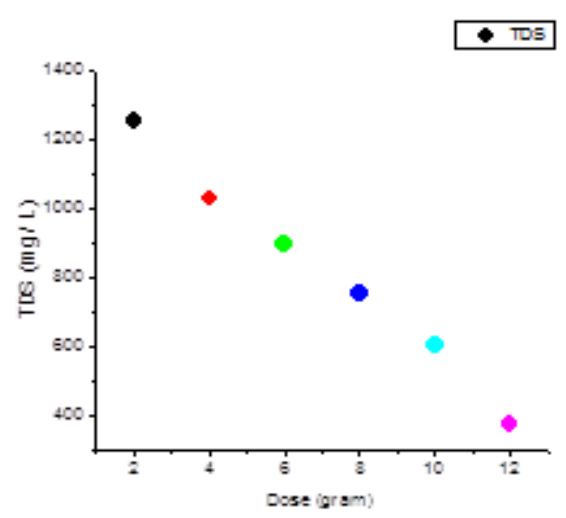

Fig.-8: Effect of TDS on the removal of Lead $(\mathrm{Pb})$

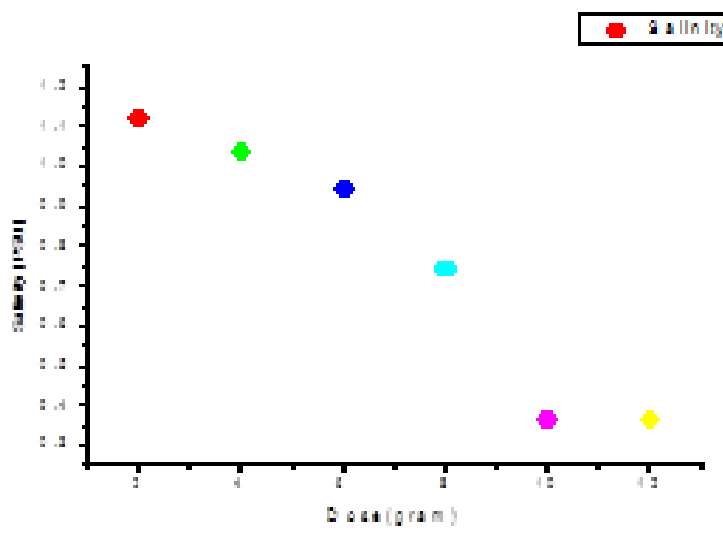

Fig.-9: Effect of Salinity on the removal of lead $(\mathrm{Pb})$

\section{CONCLUSION}

The batch adsorption process is used for adsorption of Lead from a synthetic water solution on sandstone as a low-cost adsorbent. The sandstone proved to be effective for significant uptake of Lead ions from the synthetic solution. Sandstone is easily available on mining site as waste materials can be used for the treatment of toxic heavy metal leaden effluents containing Lead ions, thereby reducing the toxic effects posed by these metals to the environment. The batch adsorption tests were conducted in the laboratory, the maximum uptake of Lead (90 to $100 \%$ ) was found in the $\mathrm{pH}$ range (3 to 5).It also reduces total dissolved solids, electrical conductivity and salinity $70.3 \%, 65 \%$, and $68 \%$ respectively.

\section{ACKNOWLEDGEMENT}

The authors would like to thank, Department of Mining Engineering, Indian Institute of Technology, and Banaras Hindu University for offering the supports for this work.

\section{REFERENCES}

1. A. Jamal, H. L. Yadav, and S.S Pandey, Euro. J. of Adv. in Eng. and Tech., 2(8), 16(2015).

2. H. L. Yadav, A. Jamal, International Journal of Advance Research, 4 (6), 310(2016).

3. M. Kobya, E. Demirbas, Ince, E. M. Senturk, Bioresour. Technol., 96, 1518(2005).

4. T.G. Chuah, A. Jumasiah, I. Azni, S. Katayon, S.Y.T. Choong, Desalination, 175,305 (2005).

5. M. Imamoglu, O. Tekir, Desalination, 228, 108(2008).

6. Gunay, E. Arslankaya, I. Tosun, J. Hazard. Mater., 146, 362(2007).

7. Y. Mido, M. Satake. Publishing House, New Delhi, (1995).

8. A. Alcolea et al., Miner. Eng., 26, 86(2012).

9. H. Davies, P.Weber, P. Lindsay, D. Craw, and J. Pope, Sci. Total Environ., 409(15), 2971(2011). 
10. S. K. Srivastava, V. K. Gupta, and D. Mohan, J. Environ. Eng. Div., 123(5), 461(1997).

11. S.Y. Quek, D.A.J. Wase, and C.F.,Water SA, 24(3), 251(1998).

12. M. Robert Brooks, Mozhgan, Bahadory, Fernando Tovia, and Hossein Rostami, Int. J. of Soil, Sedi. and Water, 3 (2), 1(2010).

13. A. Navas-Acien, E. Guallar, E.K. Silbergeld, S.J. Rothenberg, Environ. Health Perspect., 115,472(2007).

14. T.J. Woodruff, A. Carlson, J.M. Schwartz, L.C. Guidice, Fertility and Sterility, 89(2), 281(2008).

15. D. Asandei, L. Bulgariu, E. Bobu, Chem. Technol., 43, 211(2009).

16. P. J. Landrigan, E. K. Silbergeld, J. R. Froisnes, Am. J. Public Health, 80, 907(1990).

17. WHO (World Health Organization),Guidelines for Drinking-water Quality. Fourthed. World Health Organization, Geneva. (2011).

18. ATSDR (Agency for Toxic Substances and Disease Registry), 2015.

19. M. Ahameed, M.K.J. Siddiqui, Clinical Nutrition, 26,400(2007).

20. M. Ahmaruzzaman, Advances in Colloid and Interface Science, 166, 36(2011).

21. J.W. Moore, S. Ramamoorthy, Springer, New York, NY (1984).

22. B.L. Martins, C.V. Cruz, A.S. Luna, C.A. Henriques, Biochem. Eng. J., 27, 310(2006).

23. USEPA (U.S. Environmental Protection Agency), (2015).

24. M. Polat, E. Guler, G. Akar, H. Mordogan, U. Ipekoglu, H. Cohen, J. Chem. Technol. Biotechnol., 77,372(2002).

25. D. Bhattachayya, A. Jumawan, G. Sun, K. Schwitzebel, AICHE Symposium Series, Water, 77,31(1980).

26. T.N. Lung, Hydrometallurgy, 17,113(1986).

27. M.M. Matlock, B.S. Howerton, D.A. Atwood, Water Res., 36, 4757(2002).

28. J.M. Hammarstrom, P.L. Sibrell, H.E. Belkin, Appl. Geochem., 18, 1705(2003).

29. M.M.G. Chartrand, N.J. Bunce, J. Appl. Electrochem., 33, 259(2003).

30. P.M. Michalakos, Journal of Catalysis,140(1), 226(1993).

31. D. C. Feng Aldrich, H. Tan, Miner. Eng., 13,623(2000).

32. D.R. Jenke, F.E. Diebold, Water Res., 17, 1585(1983).

33. A.L.Tarleton, G.E,Lang, R.K. Wieder. Proceedings of the Symposium on Surface Mining, Hydrology, Sedimentology and Reclamation, University of Kentucky, Lexington, KY, 413(1984).

34. S.Babel, T.A Kurniawan, J. Hazard. Mater., 97, 219(2003).

35. N.Y. Deorkar, L.L. Tavlarides, Environ. Prog., 17,120(1999).

36. H .L. Yadav and A. Jamal, International Journal of New Technologies in Science and Engineering, 2(3), 77(2015).

37. L. R. Dole, Environmental Remediation Consultant, PQ Corporation. (2004).

38. S. Doyurum, A. C. Elik, J. Hazard. Mater., 138 (1), 22(2006).

39. J.S. Kwon, S.T. Yun, J.H. Lee, S.O. Kim, H.Y.J. Jo, Hazard Mater., 174, 307(2010).

40. Y. Li, Q. Du, X. Wang, P. Zhang, D. Wang, Z. Wang, Y. Xia, J. Hazard. Mater., 183,583(2010).

41. S.W. Lin, R.M.F. Navarro. Chemosphere, 39(11), 1809(1999).

42. M.M. Nassar, K.T. Ewida, E.E. Ebrahiem, Y.H. Magdy, Adsorpt. Sci. Technol., 22, 25(2004).

43. D. Petruzzelli, M. Pagano, G. Tiravanti, R. Passino, Ion Exch., 17(3), 677(1999).

44. A.Saeed, M. Iqbal, M.W. Akhtar, J. Hazard. Mater., 117(1), 65(2005).

45. S.K.R. Yadanaparthi, D. Graybill and R. Wandruszka, J. of Hazard Mater., 171,1(2009)

46. H. L. Yadav, A. Jamal, International Advanced Research Journal in Science, Engineering and Technology, 3(11), 116(2016).

47. H. L. Yadav, A. Jamal, Rasayan J.Chem.,10 (3), 891(2017).

48. US EPA report, 14010 DYG8/71,Washington, DC, (1971).

49. M.R. Lasheen, N.S. Ammar, and H.S. Ibrahim, Solid State Sci., 14(2), 202(2012).

50. M.M. G.P. Rao, K. Rao, N. V. Seshaiah, M.C. Choudary, Wang, Waste Manage., 28(5), 849(2008).

51. Q. Zhang, T. Zhou, X. Xu, Y. Guo, Z. Zhao, M. Zhu, X. Huo, Science of the Total Environment, 410, 53(2011).

52. O.S. Amuda, A.A. Giwa, and I. A. Bello, Biochem. Eng. J., 36(2), 174(2007).

[RJC-1775/2017] 